\title{
The Landscape Representation of the Anglo-Irish Cultural Estrangements in Bowen's The Last September
}

\author{
Yena Wang \\ School of English Studies, Shanghai International Studies University, Shanghai, China
}

\begin{abstract}
The isolation of the Anglo-Irish landscape is the geographical representation of the colonizer community's cultural estrangements since their settlement in Ireland till the 1920s. The depressing Irish landscape presented in the novel is a best expression of the existing state of the Anglo-Irish community: threatened, isolated, estranged and set in dilemma. The constituents and arrangements of the Anglo-Irish landscape: the Big House, its garden and the surroundings are actors who can tell the story about the living condition, social relationships and beliefs of the Anglo-Irish Ascendancy in the last days in Ireland.
\end{abstract}

Index Terms —Elizabeth Bowen, The Last September, the landscape representation, cultural estrangements

\section{INTRODUCTION}

From the perspective of cultural geography, the colonial landscape carries class consciousness and national identity "wrapped up in the estates of the landed property" and can be read as illustrations of the characters' beliefs, values, and the political connotations, as well as their predicaments in The Last September (Mitchell D, 2000, p.119). Mike Crang believes that, the geographical elements "symbolize the division in rural life" and "the division of the landscapes" with the park and trees as "part of the complex constellation of meanings and values" (p.35-36). As Vera Kreilkamp writes, "such distances between the gentry home and the village [...] suggest both the social isolation and defensive self-sufficiency of Anglo-Irish life and the spatial barriers that the Big House had erected against Catholic Ireland by the early twentieth century" (1998, p.8-9). Place and time in those novels are not just the setting of backdrops for human behavior, but problematic, personified and metaphorized between lines and beyond lines.

\section{THE IsOLATION OF COLONIAL LANDSCAPE}

Between the protestant gentry and their tenants, there is always a gulf in position and power under the British colonization of Ireland since the $17^{\text {th }}$ century. The Anglo-Irish community is privileged over the Irish population with their continued ownership of Irish land based on colonial relations. Their privileged position is enforced by the acres of vast land and those high solid Big Houses as symbols of power, position, as well as segregated isolation from the common vast Irish population. Bowen regards "isolation" as one of the most inherent and common characteristics of the Anglo-Irish manors no matter Bowen's Court of the Bowens or Danielstown of the Naylors in the novel. They usually are located in a forest, or mass of trees in an "avenue under the beeches" (Bowen, 1998, p.206). Bowen ever describes the big houses in Bowen's Court:

Each of these family homes, with its stables and farm and gardens deep in trees at the end of long avenues, is an island - and, like an island, a world. Sometimes for days together a family may not happen to leave its own demesne. ... Each of these houses, with its intense, centripetal life, is isolated by something very much more lasting than Persica, the physical fact of space: the isolation is innate; it is an affair of origin. (Bowen, 1984, p.19-20)

In Bowen's memories, Bowen's Court is isolated by the vast "farm and gardens deep in trees" with a distance at the end of long avenues. It's more "an island" which is separated from the surrounding land. Excluded from the rural Irish population, the mansion thus lay in the midst of an insulating sea of turf, hidden by trees. Thomas Henn, another former resident of an ascendancy estate, emphasizes their isolation from the surroundings in Ireland: "The avenue that leads off the main road will be long, winding, perhaps as much as a mile" (1976, p.208). This distance between the gentry's estate and the native Irish dwellings sets special barriers and indicates the isolation and estrangement, both geographical and social, of the Anglo-Irish community by the early $20^{\text {th }}$ century. Such a distance is proved to be incomparable for they are symbols of imperial classifications and it is irresistible that the conflicts go into violence in the final stage of colonization. Bowen regards this "isolation" as one of the most inherent and prominent feature of the Big Houses, including Bowen's Court of the Bowens and Danielstown of the Naylors.

\section{A. The Isolation of the Anglo-Irish Mansions}

The first landscape to be described in The Last September is the open, empty and isolated countryside. The narrative opens with an introduction of the open rural Cork land to the readers. This sense of openness, emptiness and isolation is 
developed and maintained throughout the text primarily through the repeated expression of views seen from or of the big house. We find its loveliness, but more a world of divisions and separations: looking "from the steps over a bay of fields between the plantations", there is "an ocean of space" (Bowen, 1998, p.36). Symbolically, the vast space between Danielstown and Peter Cooner's farmhouse stands for the distance between the Anglo-Irish community and the Irish community, "between the conventional and the actual, accepted and excluded, the private life and the political" (Gill, 1987, p.55). Aloof from the villages, it lies within its demesne, sheltered by trees, backed by mountains. With vitality and devouring power, "the screen of trees that reached like an arm from behind the house - embracing the lawns, banks and terraces in mild ascent-had darkened, deepening into a forest" (Bowen, 1998, p.22). Lois watches it from a faraway road of the mountains:

Looking down, it seemed to Lois they lived in a forest; space of lawns blotted out in the pressure and dusk of trees. She wondered they were not smothered; then wondered still more that they were not afraid. Far from here, too, their isolation became apparent. The house seemed to be pressing down low in apprehension, hiding its face, as though it had her vision of where it was. It seemed to huddle its trees close in fright and amazement at the wide light lovely unloving country, the unwilling bosom whereon it was set. (Bowen, 1998, p.66)

Bowen depicted the smothering quality of the Big House in a way of landscape painting. As "the grey of the lawns, like smoke" steadily mounted the house, Lois looks down at Danielstown bathing in the kitchen smoke from the road above, feeling like the big house inhabitants "living in a forest". While instead of a color of green, Bowen paints the picture with a "darkness" extending into the localized evening gloom; The demesne trees of Danielstown "make a dark formal square like a rug on the green country" (1998, p.66). The darkness, together with a silence Lois often suffers in Danielstown enforces a depressing nature of colonial landscape. Surrounded by lawns, trees and hidden in thick leaves, it is cut off from the lives of the tenants, displaying its stories of failure and declination. The houses become the most powerful narrative symbols in architectural forms telling the story better than personages. They house a big Anglo-Irish family and within its circle, and social activities such as dancing, card playing, tennis parties and conversations go on as usual with an exclusion from the outer world of conflicts by the rural proof of dense trees and vast lands. This art of presentation is more like Chinese wash painting which brings an art of tranquility. But here it presents more likely a bleakness and desolation of the Anglo-Irish manors.

This isolation is highlighted by the transport between the two neighboring big houses, Castle Isabel and Castle Trent, and the nearby garrison town of Clonmore. Remoteness lie between the sites and people need motor out to town and to go on the usual social routine among the big houses as the visits, lunches and tennis afternoons with the neighbours. And there is dependency on post and telecommunications for contact with the outside world. Cars are hired for excursions, news is brought by the postman, letters and telegrams relay information, and the nearest telephone is "six miles away" at the Ballyhinch post office (Bowen, 1998, p.78). There is much significance of telephones, radios, and newspapers in Bowen Anglo-Irish novels like The Last September, which serves to relay the tension between sociability and isolation. And Bowen's emphasis on visiting and visitors can also be seen to heighten the isolated state of Danielstown.

With its architectural outer form and inner structure, the Anglo-Irish manor houses indicate a class separation and incompatibility between the two communities. Bowen conceives her Irish home, Bowen's Court as a symbol of permanence and continuity, a refuge against the chaos of Nazi bombings. In "The Big House", Bowen ever talks about the structure of the Big House: it was designed as "a social one... with huge public rooms and staircases"; "the servants' lives were to be screened from or literally buried out of the sight of the social spaces of the house", while of the out buildings only the stables "for horses ranked very highly" (Bowen, 1998, p.26-29). With a born pride, Bowen describes how she grew up in Dublin society as a child of the Anglo-Irish and how she spent the summer in Cork at Bowen's Court. For her, the Catholics were aliens, who were simply "the others whose world lay alongside ours but never touched" (Bowen, 1986, p.25). The Anglo-Irish people are born with pride and a hierarchical notion although the landlords are kind to the tenants and they seem to be getting on well with each other. In its outer construction form, the big houses are higher in position than the Irish cabins in the basin fields, prominent from the surroundings. Seen from above, Danielstown is the "highest of all with toppling immanence, like a cliff" (Bowen, 1998, p.30) and white in color, surrounded by the thick leaves of the far-reaching trees, isolating itself with the rest of the land where the Irish dwellers live. When Bowen's close friend Seàn O'Faolàin read The Last September in the 1930's, he thinks 'the wall between Danielstwon and Peter Conner's farm" was "as high as ever" (Bowen, 1998, p.5). The high solid wall serves as a manmade obstacle between the two groups of people.

\section{B. The Separation of the Irish Landscape}

Far away from the Big Houses is the world of Irish peasants and tenants, whose landscape is always hovered by a mist of fog and kitchen smoke "lying over the vague trees doubtfully" (Bowen, 1998, p.67). The Irish dwellings are smaller in size, lower in position, insignificant in social existence. The Irish Catholic tenants are the minor characters impressionistic in The Last September, whose role is to suffer poverty, disease and death in wars. There are a tenant Peter Conner in a smoky cabin, a local rebel and his mother, a laundress at Castle Isabel, a gardener's son at Castle Trent, a neighbouring Mrs. Gegan, and the postman and postmistress at Ballyhinch. Their minimal interaction with the Anglo-Irish people does occur in the narrative of the novel to intensify an isolated situation of the Anglo-Irish from the wider human landscape of the time. Kitchen smoke, massed trees, and shadow of sunset protect the cabins from the Big 
Houses of their landlords. The native population and their way of life are kept invisible within the Anglo-Irish manors. With a big distance in space, position and relationship, there are not much intercourse and radical aggressions by the natives. In doing so, the text captures the artery of the desolation in this Irish landscape. Both parties of space seem to have been cursed by history, with a deep sense of isolation and indifference.

The isolated landscape, together with a separated situation of the Anglo-Irish, dramatizes the tensions between several social groups: the Anglo-Irish Ascendancy, the Irish peasants, the Protestant ascendancy gentry, a growing Catholic middle class; and the mass of indigenous, rural Catholic tenantry. There flews undercurrent of hostility from the Irish for only those in lower position can feel the agony to be servants under colonialism. Whatsoever, it is nationalism, colonialism, religion, class and history that makes such a situation of isolation of the Anglo-Irish and the depressing spaces are the artistic representation of the Anglo-Irish predicaments. This landscape, which is typical to all Big Houses, metaphorically symbolizes the ascendancy's social isolation from the local Irish community. In her later fiction, Bowen extends her symbols of isolation and rootlessness in urban houses, city flat, provincial villas, forlorn hotels, country cottages in To the North, The Death of the Heart and The House in Paris etc.

By this natural separation in geography and in atmosphere, Bowen transmits a sympathetic feeling more than blames towards her ancestors. The pattern of the Big House accommodates Bowen's Anglo-Irish family with a natural segregation between master and servants, the landlords and the native Irish. Bowen clears the air in Bowen's Court that, the majority of the Irish people are treated with respect and tolerance. The property-owning ascendancy class gets their elegant domination and are "ruling" the Irish in a rational and humanistic way based on their morals and disciplines. The gentry are still considered by the Irish "anathema": "they could buy service; they could not buy good regard. They were confronted everywhere by cryptic faces or disparaging smiles. The vanished old order still held the country people in a thrall of feeling" (Bowen, 1984, p.87). A neighboring Catholic George O'Brien, who lives in an Irish village near Bowen's Court, offers his attitudes for the ascendancy: the conquerors of his land were rapidly brutalized than civilized by the land" and "once ownership became a synonym for living - then the beauty turned terrible" (Bowen, 1984, p.83). For the Irish, the Big House evoked memories of exploitation and injustice, and even a remote and glamourous power as social position and wealth.

\section{The Ambivalence OF THE ANGLO-IRISH COMMUNITY}

Moreover, such a depressing landscape of isolation symbolizes the "ambivalence" between British and Irish identities of the Anglo-Irish community. The term ambivalence is "first developed in psychoanalysis to describe a continual fluctuation between wanting one thing and wanting its opposite" and is adopted into colonial discourse theory by Homi Bhabha and describes "the complex mix of attraction and repulsion that characterizes the relationship between colonizer and colonized" (Ashcroft et al., 2007, p.10). Bowen describes their ambivalent situation in the preface to the second edition of The Last September, "inherited loyalty to Britain - where their sons were schooled, in whose wars their sons had for generations fought, and to which they owed their 'Ascendancy' lands and power-pulled them one way; their own temperamental Irishness, the other” (Bowen, 1962, p.202). By origin, they are mainly the Protestant Ascendancy who own the land, estate and influence to English domination, and owe a loyalty to the Crown. They get their every relation with the mother land with the younger generations studying in England and fighting for England. The Anglo-Irish never feels completely at home in either culture. Among the English, they felt Irish and among the Irish, they felt English. With an unloving mother England and a refusal stepmother Ireland, the Anglo-Irish is destined to be lonely, expelled and executed in history. They swing frequently between the two and always suffer from cultural and identical estrangements since they set their feet on this land. Such is also the case for Bowen herself. Hermione Lee argues that Bowen deals with this dual citizenship of Bowen by deciding to "live the most Anglicized kind of Anglo-Irish life, to write as much of English themes, and out of English and European influences, as of Ireland, and to submit, thus, in her art as well as in her life, to the disappearance of the Ascendancy" (1999, p.42).

The Naylors in The Last September get all kinds of connections with Britain. And like other Anglo-Irish family, they tend to believe in the British education and send their children educated in English universities. Laurence is such an Oxford student who is so intellectual and sarcastic that Francie "had no idea how to talk to him" (Bowen, 1998, p.21). The Naylors in the novel get mingled with two cultures and have formed a romantic, stabilized and "harmonious" lord-and-tenant relationship with the surrounding communities. They know well the local Irish family, the Connors from generations and are very kind to their tenants. There is no doubt Mr. Richard and Lady Myra Naylor are the respective patriarch and matriarch of Danielstown and ideally kind landlords to the Irish peasants. They are more willing to stay in Ireland as long as they can if history permits. When the Anglo-Irish community is becoming more and more Irish-Irish, they are losing their features of their Britishness. In a time of wars between the two groups, the Anglo-Irish people's position and attitude become awkward and feel an inability to fit in either Irish or English society. They get used to the mixture of two but can never find a proper position for themselves. The Anglo-Irishness indicates a mixture of the two parties, as well a state of identity ambivalence and cultural estrangements.

The Naylors are representatives of a typical Ascendancy family in many Anglo-Irish literary creations: a weak father and an influential mother who interferes and controls in every scene, which indicates the paralysis of the Anglo-Irish. Here is a "Richard who could hardly handle a jug without dropping it and Myra who would not have him otherwise" (Bowen, 1998, p.18). Richard cares nothing about Lois's love affair with young subaltern Gerald, while Myra tries to 
interfere and even to put a stop to it. Marda, another visitor to Danielstown judges that "there is something in Lady Naylor's eye: a despairing optimism" (Bowen, 1998, p.81). She is talkative and strong determined, while Sir. Richard often becomes invisible in many conversations. Otherwise he would be interrupted by Lady Naylor. Richard gets no English confidence and arrogance, and is rather more Irish in his weakness and snobbishness. Through her way of speaking and her interference with everything in Danielstown, Lady Naylor sets herself as a male role in the family. The Anglo-Irish parallels with the Naylors of Danielstown: weak, aged, childless and doomed. The fruitlessness is the most brutal curse for the English imperialism on the land of Ireland.

The Anglo-Irish community's political and social ambivalence and their individual identity dilemma are best illustrated by a quality of hospitality, their "not-noticing" policy towards wars and the individual experience of predicaments. As intruders and landlords in Ireland for hundreds of years, the Anglo-Irish get rooted in Irish soil with a conflicted feeling of ambivalence, whereas the Irish attitude toward the Anglo-Irish is in some cases more hostile, which can be derived from characters from The Last September: the hospitality of Sir Richard and Lady Myra Naylor versus the hostility of the IRA gunman in the deserted mill. Most members of the Anglo-Irish Ascendancy do not feel a sense of Britishness which is irreconcilable with their Irish identity. Cyril Connelly, a friend of Bowen, feels it a "deadly insult" when he is teased by Anglo-Irish cousins for being English and he interprets it to mean "a combination of snobbery, stupidity, and lack of humour" (Glendinning, 1978, p.16). In contrast, he prefers to be Irish in nature and he believes the Anglo-Irish are "better born, but less snobbish; cleverer than English and fonder of horses; they were poorer no doubt but with a poverty that brought into relief their natural aristocracy" (Glendinning, 1978, p.16). The complicated nature of the Anglo-Irish's hybrid identity gives them mixed feelings about their relationship to the English.

\section{A. The Hospitality Code of the Anglo-Irish}

First of all, their cultural estrangements are illustrated by the hospitality tradition in Danielstown, which is traced down from their English gentleman ethic and a patently communal virtue as the "refinement and ritualization of neighbourliness into patterns to grace the interactions of everyday life" (DiBattista, 2007, p.227). In the midst of the Anglo-Irish War and the world outside Danielstown is filled with guns and death, turbulence and unease, violence and destruction, while the routine life of the Naylors as visiting, parties, love and hate going on as usual in the community. The stylistic hospitality governs the community and the politeness preserves a culturally coherent life style in the big house. The principle of approaching pleasure emerges and becomes the governing ethic of the big house during a time of turbulence. The Big House is a space planned for "hospitality above all", aspired to transform the Ascendancy's historical aloofness into a hospitable accommodation with the situation (Bowen, 1986, p.26). With a habit of hospitality, the gentry's house molded by Bowen is a lovely, isolated Big House which functions as the stage, a symbol, a metaphor, and most of the time, a character in Bowen's fictional world. It opens always for strangers and the stranger is the friend in this ethic of hospitality. The narrative of the novel opens with a hospitable welcome for the nostalgic return of the family friends long-time friends, Hugo and Francie Montmorency, after an absence of twelve years; it closes with the burning down of the house after a raid; and in the middle, it is filled with three arrivals and departures of the visitors from the manor house. Together with its master, the big house makes the effort to remain hospitable by its interactions with its many visitors.

During the time of troubles, there are still frequent arrivals and departures of the characters to and from Danielstown in Cork: The arrivals of the Montmorencies, the visit of Miss Norton and the departure of Gerald, construct a spatial frame, as well as a social net for the characters. The Big House welcomes the Montmorencies more warmly than its owners in a hospital way: "All the way up the house the windows were open; light came diagonally from window to window through corner rooms...the mansion piled itself up in silence over the Montmorencies' voices" (Bowen, 1998, p.8). Sometimes silent, in comparison to the loud greetings below stairs, the house opens not only its doors to the newcomers, but its windows also to embrace the exhausted travelers. Its natural light upstairs comes to the corner rooms suggesting a sense of hospitality which it manages maintain to the very end when "the door stood open hospitably upon a furnace" (Bowen, 1998, p.206). Here come Hugo and Francie Montmorency, with much "dust" brought from faraway England. Full of dust of the long journey, they "swept in" and "their exclamations, constricted suddenly, filling the hall" (Bowen, 1998, p.8). Adrift in corners of the world and moving between the various homes of their close acquaintances, the Montmorencies belong to Bowen's drifting characters in many of her fictions. After a long journey to Ireland, the word "dust" is repeatedly uttered by Mrs. Montmorency. "“Aren't we too terribly dusty!' And a tired look came down at the back of her eyes at the thought of how dusty she was." (Bowen, 1998, p.7) And when Lois is talking about Francie with Laurence, she says, "And she would do nothing but say she was dusty, and of course she was dusty, so there was nothing for me to say". Dusty is the wariness of the travel, and it is also the dead ashes of the travelers' heart.

\section{B. The "Not-noticing" Code of the Anglo-Irish}

Second of all, the Anglo-Irish holds "not-noticing" code as their defensive policy to cope with their ambivalent position and cultural estrangement predicaments in wartime Ireland. Corcoran declares that this refusal to admit the reality of war and the ascendancy's decline are a part of the Big House culture: "'not noticing' the reality of their circumstances" is "a refusal to admit to the fact that an increasingly appalling guerrilla war is about to extirpate them for ever from the land they have lived on for generations" (2004, p.46). Towards the crucial national tensions and 
conflicts outside the big house, the Naylors would rather bury their heads in the sand towards reality. They would "never listen" and "made it a rule not to talk, either" (Bowen, 1998, p.26). Euphemisms like "things" or "it" are usually used as a substitute for wars, guns and troubles. When Laurence claims things seem to be "closing in" and "rolling up", Lady Naylor interrupts him by "Ssh!" She refuses to admit the crucial situation outside by assuming "all young men from Oxford exaggerate" (Bowen, 1998, p.25). Upon the approaching collisions between Anglo-Irish and Catholic society and ignorant of political and social realities, they pretend to be in continuity of their Anglo-Irish life. Wars are happening ups and downs, though not intentionally depicted, while Sir Richard cares much about "how much of his corn had been 'laid' by the rain last night" (Bowen, 1998, p.79). He notices the leaves of the corn, the smell of the tees, a wall of moisture and the vapors trailed on the sky, but he doesn't know how the war is going. Anglo-Irish landlords are more like the sandwich biscuit in wartime, holding this typical philosophy of escaping. Sir Richard is neither like an Englishman, nor an Irish in his way of performance. Thus, outside wars and conflicts rise one after another, the Naylors continue their decorous and civilized life, plugging their ears against the outside disturbance and continue to behave as usual as if nothing bad is happening. This art of living by "not noticing" reflects the Anglo-Irish ascendancy's political blindness and their political unconsciousness.

\section{Individual Identical Dilemma}

And finally, The Anglo-Irish cultural estrangements can be explained by individual experience of identical dilemma. Meaninglessness of existence in a context of colonial conflicts is the core of the modernist crisis for the Anglo-Irish: "the abrupt break in the pattern of history, the loss of confidence in the autonomous personality, the discontinuity of the self and the uncertainty of its contact with the outside world, the failure of social contact and communication" (Coates, 1990, p.213). Lois and Laurence are the representatives of the sober-minded and self-conscious Anglo-Irish adolescence, who sees no sense of belonging here in an Irish world and a clear future there out of the Irish land. On the contrasts, the older generations endeavor to keep the big house living style like the Naylors. Some are in a state of withering ghosts like the Montmorency couple. Hugo, with a lost love died in Danielstown, returns from a prosperous life in Canada with Francie back to Danielstown nostalgically for consolation.

Lois's ambivalence about her Anglo-Irishness can be read as the ambiguous status of the Anglo-Irish in general: torn between historical and religious ties, complicated in a national feeling linking England with Ireland. Like the Irish dominated by Anglo-Irish landlords, Lois, too, is a colonized subject, confined within Danielstown, and controlled by the Naylors' rigid Big House code. She desires an emotional fullness but finds she cannot connect herself with the events outside the house. As the niece of the Big House, her self-consciousness and rebellious nature like her dead mother make her to think independently, but trapped by the confinement represented by Danielstown. The Anglo-Irish Lois and the English soldier Gerald are representatives of the irreconcilable powers which have gone too far from each other. Lois is for the Anglo-Irish and Gerald is a personal embodiment of British imperialism. Their brief love affair with Gerald Lesworth can be considered as "a microcosm of the larger political and social conflicts developed in the book" (Jordan, 1992, p.49). Their union is destined to fall into a state of estrangements and dilemma, which has gone beyond personal relations. As a blind guardian of the British imperial order, Gerald personifies British imperialist dominance. When Laurence asks Gerald his personal opinion about the current situation in Ireland, he replies, "Well, the situation's rotten. But right is right...form the point of view of civilization" (Bowen, 1998, p.92). He thinks the British is rather civilized and he is out here doing a just thing "to hunt and shoot the Irish" (Bowen, 1998, p.93). In relation with Gerald, Lois falls into her own revelry feeling "cold", "lonely" and "vacant" when Gerald tries to kiss her in the hut. She cannot respond to Gerald's desire in an adult way. Between bursts of laughter, she feels Gerald "look at her lips, at her arms, at her dress like a ghost, with nostalgic and cold curiosity" (Bowen, 1998, p.158). The love and proposals from Gerald provides no consolations for her loneliness and her sense of uncertainty due to his dominating imperialistic and sexual exploitative attitudes towards her. So in the end, Bowen endows her with a promising space - an art school in France, as Elizabeth Bowen has does, leaving the Naylors watching the burning house into wreckage.

\section{CONCLUSION}

To sum up, the isolated colonial landscape in The Last September is the metaphorical representation of the characters' estranged state of living. Characters are colonized subjects like Ireland itself, confined within a colonial estate, Danielstown, and the rigid Big House code. Personal ambivalent predicaments have gone into the realm of the Anglo-Irish community's field. As the planters, landlords, colonizers, they keep the hospitality tradition of the Big House, hold not-noticing code for the social turbulence and political wars. Whist they are suffering from the cultural estrangements of identity ambiguity but finds no way out, waiting for the coming of the doom days. Bowen employs an art of ink painting in representing the spatial elements to symbolize the isolated state of the Anglo-Irish ascendancy community. Starting from a vast, open, isolated colonial countryside, she constructs the separated, classified and independent spaces for the Anglo-Irish and the Irish. The Big House, isolated, threatened, estranged, and set in a historical situation of dilemma, together with its masters, stands in Ireland lonely waiting for its execution in the end. 


\section{REFERENCES}

[1] Ashcroft, B., Gareth G., and Helen T. (2007). Post-Colonial Studies: The Key Concepts. 2nd ed. London and New York: Routledge.

[2] Bowen, E. (1998). The Last September. London: Vintage.

[3] Bowen, E. (1984). Bowen's Court and Seven Winters: Memories of a Dublin Childhood. London: Virago.

[4] Bowen, E. (1986). "The Big House." The Mulberry Tree: Writings of Elizabeth Bowen. Ed. Hermione Lee. London: Virago, 25-30.

[5] Bowen, E. (1962). "Prefaces." Seven Winters: Memories of a Dublin Childhood \& Afterthoughts: Pieces on Writing. New York, Alfred A. Knopf, 197-204.

[6] Coates, J. (1990). "Elizabeth Bowen's The Last September: The Loss of the Past and the Modern Consciousness." Durham University Journal. 82.2, 205-216.

[7] Corcoran, N. (2004). Elizabeth Bowen: The Enforced Return. Oxford: Oxford UP.

[8] Crang, Mike. (1998). Cultural Geography. London \&New York: Routledge.

[9] DiBattista, M. (2007). "Elizabeth Bowen's Troubled Modernism." Modernism and Colonialism: British and Irish Literature, 1899-1939. Ed. Richard Begam and Michael Valez Moses. Durham, NC: Duke University Press, 226 - 45.

[10] Gill, R. (1987). "The Country House in a Time of Troubles.” Elizabeth Bowen. Ed. Harold Bloom. New York: Chelsea House, 51-62.

[11] Glendinning, V. (1978). Elizabeth Bowen. New York: Knopf.

[12] Henn, T. (1976). "The Big House.” Last Essays: Mainly on Anglo-Irish Literature. New York: Harper and Row.

[13] Jordan, H. B. (1992). How Will the Heart Endure: Elizabeth Bowen and the Landscape of War. Ann Arbor: University of Michigan Press.

[14] Kreilkamp, V. (1998). The Anglo-Irish Novel and the Big House. New York: Syracuse University Press.

[15] Lee, H. (1999). Elizabeth Bowen. London: Vintage.

[16] Mitchell, D. (2000). Cultural Geography: A Critical Introduction. Oxford: Blackwell Publishers Ltd.

Yena Wang was born in Linyi, China in 1979. She is a PH.D. student of Arts in Shanghai International Studies University, China. Her research interests include British and American literature, comparative literature etc. 